\title{
1. Introduction: geography, open innovation and entrepreneurship
}

\section{Urban Gråsjö, Charlie Karlsson and Iréne Bernhard}

To secure incomes and welfare in the long run, rich developed countries need to be very innovative to improve or even preserve their competitiveness against international competition. The challenge is to meet the demands and wishes of actual and/or potential customers better than all other competitors, to fully exploit their willingness to pay. Thus, the ability to innovate is critical, since innovation is a key driver of productivity growth (Hall, 2011; Mohnen and Hall, 2013). Productivity is increased through the introduction of new goods and services, new methods of production and novelties in their organizational and marketing practices.

An innovation can be defined as the localized generation of an idea, behaviour, system, policy, programme, device, process, product or service that is new to and represents a potential economic value for the economic agent (Damanpour, 1992). It is the result of an open, dynamic, non-linear, evolutionary, knowledge-intensive and time-consuming process (Link and Siegel, 2007) in which both internal and external knowledge and actors are used to create new combinations of resources (Chesbrough, 2003). Innovations are generated by two types of economic agents: incumbent firms and entrepreneurs. The relative role of these two types of economic agents for innovation has been extensively discussed all the time since Schumpeter $(1934 ; 1942)$ wrote his famous books. Here, we focus on two specific but interrelated aspects of innovation by these two types of economic actors, namely the role of geography, that is, the location of economic agents, and of open innovation, ${ }^{1}$ respectively.

1 We must acknowledge that there is a lack of clarity and some dissatisfaction with how the concept has been used (Dahlander and Gann, 2010). Innovation has to a certain extent always been open. 
It is a basic assumption that a single economic agent cannot innovate in isolation. Thus, the open innovation paradigm ${ }^{2}$ treats the innovation process as an open process, where ideas, knowledge and resources valuable for innovation can come from both inside and outside the economic agent. ${ }^{3}$ Useful ideas and knowledge are widely diffused in society (Hayek, 1945), which implies that innovating economic agents must be able to identify, connect to, evaluate and access these ideas and knowledge by establishing an innovation network. The focus in the literature is almost entirely on open innovation in incumbent firms, but what we will show here is that open innovation is actually typical for innovation by entrepreneurs. A further point that we want to stress is that the conditions and options for open innovation are functions of the location of economic agents. This leads to two fundamental questions:

- How does openness influence the ability of incumbents and potential entrepreneurs to innovate and to appropriate the benefits of innovation?

- How is this ability influenced by the location of incumbents and potential entrepreneurs?

By discussing these factors in this introductory chapter, we create a background and a foundation for the rest of the chapters in this edited volume. The chapter is organized as follows. In Sections 1.1 and 1.2 we discuss innovation by incumbent firms and by entrepreneurs, respectively. Section 1.3 is devoted to a discussion of the role of location or geography for innovation. In all three sections, we especially emphasize open innovation. In Section 1.4, we briefly present the content of the rest of the chapters in this edited volume.

2 The open innovation literature is quite tricky, since it mixes a positive and a normative approach (cf. Chesbrough, 2003, XXIV): 'open innovation is a paradigm that assumes that firms can and should use external ideas as well as internal ideas, and internal and external paths to the market, as firms look to advance their technology'.

3 Open innovation is often defined very vaguely, which has led to conceptual ambiguity. Chesbrough et al. (2006, 286) claims, for example, that 'open innovation is both a set of practices for profiting from innovation, and also a cognitive model for creating, interpreting and researching those practices'. 


\subsection{INNOVATION BY INCUMBENT FIRMS}

The ability of firms to innovate is a fundamental requirement for the renewal and survival of firms (March, 1991). For firms to meet the challenges in the market place, it is not enough to be excellent in product innovation. We can assume that in many cases product innovation must be complemented with process, organizational and/or market innovation. Furthermore, product and process innovations tend to require changes in how firms are organized, how their products are marketed, in which markets their products are sold and so on, which implies that organizational and market innovations are stimulated.

We claim that for firms to gain from an innovation they must transform other parts of their innovation efforts, including changing the system and organization of production, marketing and delivery. The importance of considering different modes of innovation is stressed in Teece's (1986) framework for profiting from innovation, which emphasizes that the returns of innovation usually go to those firms that control valuable and rare innovative assets, which permits the development of complementary innovations. This ability to develop complementary innovations amplifies the value of the original innovation. It is obvious that firms encounter a complex task if they want to be innovative, since they often simultaneously must combine two or more modes of innovation in a complementary way.

There are several theories that highlight firms' innovation motives from different points of view (Brunow and Miersch, 2015). In Schumpeter's theory of 'creative destruction', innovation is both a key driver and a result of the profit-seeking behaviour of individual firms. Firms compete in different markets, and in each market the firms that are best at supplying product deliveries with characteristics that match the customers' willingness to pay while controlling the delivery costs will enjoy relatively higher profits. Keeping that position in the market over time demands product, process, market and/or organizational innovation but offers at the same time an opportunity to earn a monopoly rent at least in the short term. The same is true for other firms that want to compete with the leading firms with regard to the leading position in the market.

Besides trying to protect their position in the current market, firms may also increase their profits and hopefully at least temporarily earn a monopoly rent by entering other market segments in the same market or new markets. Firms that have developed new knowledge and new technologies can also make a profit in other ways, such as selling patents, 
licences for the use of patents and so on, that can represent both an alternative and a complement.

We may, in line with the resource-based view of the firm (Penrose, 1959; Wernerfeldt, 1984), assume that the probability of success is dependent upon the individual firm's tangible and intangible resources and its innovative capability, that is, its ability and skills to recruit, organize and manage different types of resources and combine them in a creative and innovative way, as well as to develop 'core' and outsource 'non-core' competencies (Takeishi, 2001). Thus, even if it is generally accepted that the internal capacities and activities in firms are critical for their innovative capacity (Lichtenthaler and Lichtenthaler, 2009), it is also widely recognized that a primary factor affecting a firm's innovative capacity is its openness to external sources of ideas, information, knowledge, technology and collaboration and hence to performing open innovation.

We assume that the following innovation input factors are critical for a firm's ability to innovate, which highlights the role of open innovation:

- Internal human capital

- Internal research and development (R\&D)

- Corporate status (single firm or belonging to a group of firms)

- Outsourcing of R\&D and the acquisition of external knowledge

- Cooperation on innovation with customers, suppliers, competitors, universities and R\&D institutes

- Engagement in exports and imports

- Firm location characteristics, for example human capital supply, material and immaterial infrastructures, market potential and industrial structure.

All these innovation input factors can be related to the innovation outputs by means of a knowledge production function (Griliches, 1979; Crépon et al., 1998):

$$
Q_{i j}=A_{i} H_{i}^{\alpha} K_{i}^{\beta} X_{i}^{\gamma}
$$

where $Q_{i j}$ is a vector representing the innovation outcome in firm $i$, where $j=1, \ldots, 4$ represents the four modes of product, process, organizational and market innovation; $A_{i}$ measures the overall labour productivity of the innovation activities in firm $i ; H_{i}$ is the human capital input in innovative activities in firm $i$; $K_{i}$ represents all other internal innovation inputs in 
firm $i$; and $X_{i}$ represents innovation inputs external to firm $i$. The knowledge production function highlights that the costs for the innovation outputs depend on the wages for the human capital input $H_{i}$, the costs of the internal innovation inputs $K_{i}$ and the costs of building and preserving the links to the external innovation inputs $X_{i}$. The parameters $\alpha, \beta$ and $\gamma$ are all positive, and their values can be smaller, equal to or larger than 1, which implies that we can have decreasing, constant or increasing returns.

A clear distinction is made between the innovation output and the innovation inputs. The basic underlying idea is that the internal and external innovation inputs (R\&D investments, information and communication technology (ICT) investments, various knowledge sources, etc.) generate knowledge, which may manifest itself in the form of one or several modes of innovation. Firms basically invest in internal R\&D because the costs of organizing R\&D inside the firm are lower than acquiring ideas, knowledge and technology from the marketplace (Mowery, 1983). Firms with significant investments in R\&D can develop an organization that streamlines the innovation process, and they can also gain economies of scale and scope from their R\&D (Henderson and Cockburn, 1996). Firms also invest in internal research and human capital to enhance their ability to search for and use external knowledge and technology in the innovation process (Nelson and Winter, 1982; Rosenberg, 1994), that is, to increase their absorptive capacity and the capability to track, evaluate and absorb new ideas, knowledge and technologies outside the firm (Cohen and Levinthal, 1990). This external knowledge and technology can be found in suppliers, customers, competitors and other external sources.

In the short run, the existing accessible internal and external innovation inputs limit the modes of innovation a firm can achieve. In the medium and long run, on the other hand, the firm can increase the number of options by investing in the internal innovation inputs and in improving links to the available external innovation inputs. Most empirical studies have focused on product innovation, but the knowledge production function framework is equally applicable when it comes to process, organizational and market innovations. Schmidt and Rammer (2007) studied the determinants of various technological and non-technological innovations and found that they were almost identical.

The external innovation inputs, $X_{i}$, are included to control for possible spillover effects from the firm's economic milieu. Despite significant investments in R\&D and strong internal competence, it is of fundamental importance for firms to search for new ideas, knowledge and technology outside their borders. These external innovation inputs may be substitutes 
for the firm's own innovation inputs and thus can make innovation less costly. However, they may also be complements to the firm's own innovation inputs and thus boost the innovation outputs of the firm at a given cost level (Arora and Gambardella, 1990; Cassiman and Veugelers, 2006). Most of the literature seems to see internal R\&D as a necessary complement to openness (Dahlander and Gann, 2010). Some authors even claim that effective innovation depends crucially on firms' capacity and ability to use complex networks to absorb distributed external knowledge and combine it with their own proprietorial knowledge (Chesbrough, 2003; Roper et al., 2008; Love and Roper, 2009).

Firms in locations with a large supply of external innovation inputs can be expected to be more innovative than firms in locations with a smaller supply of external innovation inputs, ceteris paribus, due both to the cost effect and the complementarity effect. Expressed in other words, we can say that some locations offer more developed regional innovation systems, where open innovation processes through local and regional innovation networks can thrive, than other, less fortunate locations (Andersson and Karlsson, 2006; Capello, 2014). However, it is important to observe that not every firm gains from access to a rich supply of external innovation inputs in the more developed regional innovation systems, due to a too low absorptive capacity (Cohen and Levinthal, 1990; Zahra and George, 2002).

What then can we say about the factors governing the decisions of firms to invest in innovation? We know on the one hand that investments in innovation are costly and the results are uncertain, but, on the other hand, we also know that successful innovations lead to preserved or even increased future profits. These costs and the associated uncertainty might lead smaller, more risk-adverse firms to abstain from investing in innovation. The decision whether to invest in innovation or not depends on the relationship between the expected costs of such an investment and the expected profits from such an investment. Investments in innovation will be made if the expected discounted profit exceeds the discounted costs of the investment (Baldwin, 1999). Thus, the likelihood that a firm invests in innovation increases the higher the expected profit for a given innovation investment cost as expressed by the knowledge production function.

\subsection{INNOVATION BY ENTREPRENEURS}

Following Schumpeter's original contribution, several authors have in recent decades stressed that innovation may represent a vehicle for new 
firms to enter the market successfully. Innovative entry is a central force driving competition among firms in a market economy (Dosi et al., 1997). However, since new firms, when they start up, have by definition done no R\&D of their own to generate an innovation, we need to provide a theoretical explanation of the mechanisms and/or channels through which they get the necessary knowledge inputs, that is, the technological and entrepreneurial knowledge, for generating innovations (Acs and Audretsch, 1988).

The obvious mechanism is that old as well as new technological and entrepreneurial knowledge through various channels can spill over to economic agents other than those who generated it and possibly be exploited by them. However, it is by no means a given that an economic agent possessing a certain mixture of usable technological and entrepreneurial knowledge will use it to generate an innovation. Individual economic agents differ, due to differences in education, experience and so on, in their capacity and capability to create and exploit innovations, that is, to generate new combinations out of existing technological and entrepreneurial knowledge, and thus function as change agents. One important reason for varying capacity of economic agents to become entrepreneurs is differences in terms of integration in social, business and professional networks (Szarka, 1990). Such capacity differences are important, since modern entrepreneurship is based on associated skills of a varied nature. A real entrepreneur is an opportunity seeker who in this endeavour needs an eye for, and a readiness to respond to, an often rapidly changing external environment (Nijkamp, 2003).

Having the ability and the capacity to generate a potential innovation doesn't automatically imply that an economic agent must become an entrepreneur to appropriate the potential returns from such an innovation. Of course, the potential innovation could be sold to an incumbent firm or to another potential entrepreneur. However, the problem with asymmetric information (Akerlof, 1970) often implies that the best way to appropriate returns from potential innovations is through entrepreneurial action by economic agents, that is, an organization of resources to initiate commercial activity (Bhide, 2003).

Generally speaking, two types of networks must converge for an economic agent to transform a potential innovation to a real innovation by founding a new firm (Shapero, 1984; Sorensen, 2003):

- A knowledge network. The economic agent must perceive an opportunity for a profit in a particular market segment or niche, that is, have enough economic incentive to start a new firm. Since much of the relevant technological and entrepreneurial knowledge is held 
by a number of economic agents, the identification of potentially profitable opportunities to generate an innovation requires connections to those with pertinent knowledge (typically those currently engaged in R\&D in a particular field and those currently engaged in businesses in a particular industry). Economic agents that can access existing technological and entrepreneurial knowledge relevant for a particular industry can enjoy a large advantage in identifying current innovation opportunities (Klepper, 2001; Klepper and Sleeper, 2005).

- A resource network. The economic agent that perceives an opportunity to launch an innovation must build a firm to exploit it, that is, to assemble the necessary capital, skilled labour and knowledge. Social relations and social, business and professional networks play a crucial role in acquiring knowledge and convincing resource holders to join the new venture as employees, investors, suppliers and customers. However, the wealth position of the economic agent has important effects for the probability of convincing investors to finance the endeavour.

\subsection{INNOVATION AND LOCATION}

It has become more and more obvious that location or geography is critical for creativity and innovation despite all the claims in recent decades that distance is dead and that 'the world is flat'. The conditions for creativity and innovation vary very substantially between locations. One important difference between locations is the institutional frameworks. Effective institutions bring down transaction costs and thus the costs associated with innovation. They increase the incentives to innovate through their definition and protection of intellectual property rights. Institutions offer the foundations for open innovation by facilitating knowledge flows and the appropriation of rents from innovations.

The conditions for innovation also differ between locations due to variations in demand conditions, in terms of regional market potential and demand for new goods and services. Large and dense urban regions offer an advantage for innovation by offering proximity to a concentration of (potential) customers, which to a substantial degree are incumbent firms. They also offer a positive information externality, since individual economic agents, irrespective of if they are incumbent firms or potential entrepreneurs, may receive signals about the strength and the composition of regional demand by observing the successful or unsuccessful trade of established suppliers. A large and dense urban 
region offers a regional environment of qualified and demanding customers, which can be seen as an important prerequisite for innovation. Interaction with actual and potential customers plays an important role in open innovation.

Regions vary substantially in terms of the volume and types of new ideas, knowledge and technologies that they generate due to the varying presence of universities, research institutes, innovating firms and so on, that is, organizations that are direct or indirect generators of innovation (Acs, 2000). They also differ in terms of their knowledge and commercial links to other regions. Large urban regions have concentrations of universities, R\&D institutes, R\&D firms and so on, and they are well connected to other large urban regions through rich international air connections. Firms that locate in such regions also tend to be more innovative, either through learning or sorting, that is, they draw on or adapt to their regional milieu (Doloreux, 2005). This implies that the potential for knowledge flows through knowledge transfers and spillovers also varies substantially to the advantage of large urban regions, which suggests that they offer the best conditions for open innovation. This is particularly important when the knowledge is complex and perhaps tacit in nature (Jaffe et al., 1993).

Regions differ in terms of the size of their labour supply and the education level and experience of their labour forces. Large and dense urban regions tend to attract creative and innovative people (Landry, 2008). Thus, the labour markets in these regions are particularly supportive of innovation, which makes it easier to recruit the specialized skills needed in the open innovation process and to come close to an ideal match between the jobs to be filled and the competence profile of the people in the regional labour force (McGuirk and Jordan, 2012). Highly skilled employees in thick urban labour markets tend to be more specialized than employees in thin labour markets, and they are also more experienced, since employees in thick labour markets change jobs more often than employees in thin labour markets. The easier it is for innovators to recruit exactly the right kind of highly skilled and specialized labour, the lower the innovation costs (Krugman, 1993). The time to fill vacancies is also normally shorter in thick urban labour markets. The better matching in the labour market in urban regions with thick labour markets tends to make innovators in such labour markets more productive and more innovative, which then tends to result in higher profits, making it easier for firms to finance continuous innovation. Higher productivity makes it easier for these firms to pay higher salaries, which encourages skilled labour to stay in or move to thick urban labour markets (Antonelli et al., 2013). 
Regions also differ substantially in their supply of non-traded inputs, that is, in terms of their service infrastructure and, in particular, their supply of knowledge-intensive business services. Such inputs are provided both in greater variety and at lower cost in large urban regions, which stimulates innovation (Krugman, 1991a and b). Large urban regions offer a more developed physical infrastructure in terms of access to major highways and airports, which offer benefits to innovators in the form of higher accessibility. These regions function as a nucleus of uncountable networks of different types with a spatial scale ranging from the very local to global, which are a prerequisite for open innovation (Nijkamp, 2003). Participation or involvement in various networks makes it possible to externalize some of the risks involved in innovation (Shapero, 1984).

Large urban regions with intense innovative actions offer innovators, incumbent firms and potential entrepreneurs an informational externality from observing other innovators' successful and unsuccessful attempts to innovate. There is a large potential for innovation-relevant knowledge to spill over in such regions. A special advantage for innovators in large (and dense) urban regions is reduced transaction costs. In particular, search costs for knowledge, technology, services, financing, suppliers and customers are lower in such regions (Quigley, 1998).

Large urban regions are critical for innovators, since they innovate in an open fashion, that is, they rely on face-to-face interaction with other economic agents, which is greatly facilitated by the economic milieu offered by large urban regions due to their greater physical proximity (Storper and Venables, 2004). Normally, innovation is critically dependent upon the transfer of complex, uncertain and sometimes tacit knowledge - a transfer that often needs repeated face-to-face interactions during extended periods, which are much easier to organize in large urban regions. However, large urban regions are important in another respect. They offer many more options and chances than smaller regions for unscheduled or serendipitous encounters that often result in the juxtaposition of different types of ideas, information and knowledge, which by inducing and stimulating creative processes might lead to innovations (Godoe, 2012). It is sometimes claimed that other types of proximity than geographical proximity, such as social, organizational, cognitive and institutional proximity, are important for innovation (Boschma, 2005). However, we must realize that the strength of these other types of proximity is a function of the geographical proximity of economic agents.

The implications of the above discussion are far-reaching. Since larger urban regions offer bigger opportunities, better external conditions and a 
higher capacity for innovation, as well as a higher probability of successful innovation, these regions will experience a build-up of innovation knowledge, experiences and skills, which will stimulate further innovation in these regions. Furthermore, innovators are change agents who will not only introduce innovations, and in many cases start new firms, but will also shape the regional environment and its institutions to become still more supportive to innovation (cf. Feldman, 2001). Good conditions for innovation will stimulate actual and potential innovators, often highly educated people and R\&D-oriented firms, to move to such regions. When more actual and potential innovators gather in such large regions, the conditions for innovation improve due to increased innovation knowledge and experience. This further induces innovation activities and the in-migration of actual and potential innovators in a dynamic cumulative concentration process.

However, the effects of innovation in a region go much further. Innovation implies the introduction of new products and new production processes in the regional market. Accordingly, it implies a major challenge to incumbent firms, who offer their own and/or imported products on the regional market, through increased competition, and encourages them to improve product quality and services, or to reduce prices, or to leave the market. This means that innovation plays a fundamental role in the renewal of regional economies by strengthening competition and initiating competitive processes that ultimately result in a creative destruction of existing modes of production. Innovation activities in a region contribute significantly to its economy and employment, but in particular to its renewal. Each innovation launched can be seen as an experiment. All active and potential innovators benefit from learning from the outcomes, successful or not, and the volume of such learning is proportional to the number of such experiments. Since larger urban regions normally host many more experiments than smaller regions, they also benefit more from such learning. Thus, they accumulate a larger stock of innovation knowledge and experience over time, which implies that the externalities from such learning are dynamic in nature. In a multi-regional context, each region builds up a stock of knowledge about innovation dependent upon current and past innovative activities. This accumulation of innovation knowledge affects the probability that innovative activities will take place in the future and be successful.

Large urban regions offer the best general seed-bed conditions for the launching of original innovations, and knowledge-based innovations in particular. However, the introduction of an innovation in a large urban region is not the end of the story. Instead it is a foundation for a series of subsequent innovative and entrepreneurial initiatives. In an attempt to 
maximize profits, the innovator will attempt to expand demand in the home region but also try to sell the innovation in other regions by means of export, in a process of spatial innovation diffusion. In a parallel process, incumbent firms and potential entrepreneurs in the home region, and later also in other regions, will study the innovation if it is significant and try to imitate it, which often leads to an improvement compared with the actual innovation, or try to develop an innovation that is superior to the actual innovation. Thus, the launching of innovations often induces and stimulates a competitive race where the final outcome differs from innovation to innovation. In some cases, the original innovator will be able to protect his or her innovation, often due to a first-mover advantage (Brown and Eisenhardt, 1998). In other cases, the imitators or subsequent innovators will win. In still other cases, innovators, imitators and subsequent innovators compete in the same market but often target different market segments, creating a market structure consisting of an oligopoly or monopolistic competition.

Even if large urban regions generally offer better conditions for innovation, we have to also recognize that some smaller regions can offer good conditions for innovation in certain industries or technologies, often within the framework of a specialized cluster.

\subsection{THE CONTENTS OF THIS BOOK}

Below, the contributions are summarized in the sequence in which they appear in the book so that the reader can plan their reading experience.

In Chapter 2, Russo, Caloffi, Rossi and Righi provide a theoretical framework to address the mismatch between policy objectives and indicators used to evaluate the performance of innovation intermediaries (i.e., organizations that support firm-level collaborative innovation). The authors illustrate these issues by using a case study of publicly funded intermediaries in Tuscany, Italy.

How public procurement of innovations improve the competitiveness of small and medium-sized enterprises (SMEs) is examined by Reijonen, Saastamoinen and Tammi in Chapter 3. A statistical analysis applying a path model on survey data of Finnish SMEs showed that collaborating with the public sector customer increases the chances of acquiring public sector contracts and improves firms' performance. The authors argue that the result highlights the importance of understanding customer demand when developing innovative products and services.

Studies on Public Private Partnerships (PPPs) usually indicate that PPPs can improve the quality and efficiency of infrastructure services and 
enable innovation in infrastructure developments. However, researchers do not prove whether, and in which conditions, the PPP model is capable of developing innovative solutions. Carbonara and Pellegrino aim to overcome this limitation in Chapter 4. They develop a conceptual framework that identifies the PPP features that can influence innovativeness and define how these features have to be structured in order to foster innovation.

In Chapter 5, Armellini, Beaudry and Mahon investigate the influence of the NIH (not-invented-here) and NSH (not-sold-here) syndromes for the adoption of open innovation. The authors address this issue by suggesting a regression model that captures the presence of these syndromes and their relation to open innovation. The regression model is tested with data from a survey on the adoption of open innovation practices and open business models in the Canadian aerospace industry.

Héroux-Vaillancourt and Beaudry examine in Chapter 6 whether the importance of open innovation activities is related to the innovation performance. The data used in their study is gathered from Canadian nanotechnology firms. Open innovation is observed with respect to inbound and outbound activities, open innovation in general and the use of online open innovation platforms. Innovation performance is measured by the number of product and process innovations as well as the quality of the innovations, that is, how product innovations affect the total revenue of firms. The results indicate that the different elements of open innovation have different impacts on innovation performance.

The conventional wisdom that geographical proximity eases communication and knowledge exchange is explored using a novel approach by Delbaggio, Hauser and Kaufmann in Chapter 7. By using data from Twitter, the authors recorded all tweets and corresponding replies to tweets in Switzerland during a period of time in 2015. If both the tweet and reply are tagged with a geolocation, then this communication specifies a relationship over an assessable geographical distance. The results show a strong bias of tweet-reply relationships towards short distances. While roughly only half of a per cent of all messages would occur within the same municipality in a random setting, about one-third of all observed replies were connected to a tweet from the same municipality. The authors conclude that the degree of urbanization is strongly related to the intensity of Twitter-based communication.

Chapter 8, by Johnston, Lassalle and Yamamura, proposes a conceptual framework for research on entrepreneurial ecosystems. The aim of the chapter is to contribute to the field by considering the dynamics of 
change, both spatially and temporally, within the entrepreneurial ecosystem. The authors consider the interaction of agents (i.e., the entrepreneurs) and structures (e.g., the socio-spatial and institutional environment) as co-evolving elements. They also stress that the co-evolution of actors and structures as part of the entrepreneurial ecosystems implies that the spatial range of an ecosystem may change over time.

In Chapter 9, Cornett analyses the potential conflict of targets embedded in the political objective to improve economic performance and the competitiveness of countries internationally and at the same time the need to prevent increasing regional diversity with regard to growth and wealth. Data for Germany, Sweden and Denmark show a rather stable pattern of growth: the strong regions keep their advantages and the weaker regions seem to be trapped in their structural situation. Cornett argues that policies and programmes intended to stimulate innovation and entrepreneurship tend to have a regional bias towards centre regions and sectors mainly located in urban areas. They may generate growth and strengthen international competitiveness overall, but they have significant shortcomings in less urbanized regions.

How important bank loans are for the financing of start-ups and how location matters for expansion plans and financing are important and interesting questions. These issues are analysed by Bjuggren and Emoznino Laufer in Chapter 10. The authors use survey data on Swedish start-ups and registry data to incorporate the regional dimension into the analysis. The survey data indicate that bank loans are rare. Essentially, the entrepreneur personally takes most of the business risk. When combining survey and registry data in a regression analysis, the authors found that in the three most urbanized areas, the start-up firms had plans to expand their business both at home and abroad. In the other urbanized areas, the focus was on expansion at home.

Chapter 11, by Rohde, is a conceptual framework tailored to identify locational resources and to analyse the value creation potential in cross-border clusters from a single-firm perspective. To achieve this, the author extends the resource-based view of clusters, rooted in the resource-based view of the firm, to provide a resource-based view of cross-border clusters.

The concept of path dependence is in focus in Chapter 12 by Fredin. According to Fredin, the concept has been criticized for focusing too much on external shocks and lock-ins and less on endogenous preconditions for new path development. The main aim of the chapter is to enhance the concept of regional path dependence by shifting from a purely technological dimension of path dependence to a stronger role of 
human agency. In order to move towards a more agency-centred view of regional path dependence, the author argues that we need to acknowledge the activities of many agents and include both economic and public actors.

In Chapter 13, Jordaan and Monastiriotis use firm-level data from the Greek manufacturing sector to identify how spatial heterogeneity, spatial proximity and spatial concentration influence foreign direct investment (FDI) spillovers within and across industries. The authors' main findings can be summarized as follows. First, when controlling for national, regional and local FDI participation, they find that FDI spillovers occur at sub-national levels. In particular, intra-industry spillovers materialize at the regional level, whereas inter-industry spillovers are maximized at the much finer, local level.

In the last chapter, Chapter 14, authored by Arvemo and Gråsjö, potential indicators of economic development are in focus. The authors conduct an exploratory study using Swedish municipal data contrasting economic development and growth. The chapter explores different definitions of and possible measures for economic development and how they relate to measures commonly used for studying economic growth. The main conclusions are that indicators for economic growth and economic development in some cases move in opposite directions. Hence, what drives economic growth might have a negative impact on certain elements of development.

\section{REFERENCES}

Acs, Z.J. (2000), Innovation and the Growth of Cities, Edward Elgar, Cheltenham, UK and Northampton, MA.

Acs, Z.J. and D.B. Audretsch (1988), Innovation in Large and Small Firms: An Empirical Analysis, American Economic Review 78, 678-690.

Akerlof, G.A. (1970), The Market for 'Lemons': Qualitative Uncertainty and the Market Mechanism, Quarterly Journal of Economics 84, 488-500.

Andersson, M. and C. Karlsson (2006), Regional Innovation Systems in Small and Medium-Sized Regions, in B. Johansson, C. Karlsson and R.R. Stough (eds), The Emerging Digital Economy: Entrepreneurship, Clusters and Policy, Springer, Berlin, 55-81.

Antonelli, C., F. Crespi and G. Scellato (2013), Internal and External Factors in Innovation Persistence, Economics of Innovation and New Technology 22, 256-280.

Arora, A. and A. Gambardella (1990), Complementarity and External Linkages: The Strategies of Large Firms in Biotechnology, Journal of Industrial Economics 38, 361-379. 
Baldwin, R.E. (1999), Agglomeration and Endogenous Capital, European Economic Review 43, 253-280.

Bhide, A.V. (2003), The Origin and Evolution of New Businesses, Oxford University Press, Oxford.

Boschma, R. (2005), Proximity and Innovation: A Critical Assessment, Regional Studies 39, 61-74.

Brown, S.L. and K.M. Eisenhardt (1998), Competing on the Edge: Strategy as Structured Chaos, Harvard Business School Press, Boston, MA.

Brunow, S. and V. Miersch (2015), Innovation Capacity. Workforce Diversity and Intra-industrial Externalities: A Study of German Establishments, in K. Kourtit, P. Nijkamp and R.R. Stough (eds), The Rise of the City: Spatial Dynamics in the Urban Century, Edward Elgar, Cheltenham, UK and Northampton, MA, 188-222.

Capello, R. (2014), Proximity and Regional Innovation Processes: Is There Space for New Reflextions?, in A. Torre and F. Wallet (eds), Regional Development and Proximity Relations, Edward Elgar, Cheltenham, UK and Northampton, MA, 163-194.

Cassiman, B. and R. Veugelers (2006), In Search of Complementarity in Innovation Strategy, Management Science 52, 68-82.

Chesbrough, H. (2003), Open Innovation: The New Imperative for Creating and Profiting from Technology, Harvard Business School Press, Cambridge, MA.

Chesbrough, H., W. Vanhaverbeke and J. West (2006) (eds), Open Innovation: Researching a New Paradigm, Oxford University Press, Oxford.

Cohen, W.M. and D.A. Levinthal (1990), Absorptive Capacity: A New Perspective on Learning and Innovation, Administrative Science Quarterly 35, 128152.

Crépon, B., E. Duguet and J. Mairesse (1998), Research, Innovation and Productivity: An Econometric Analysis at the Firm Level, Economics of Innovation and New Technology 7, 115-158.

Dahlander, L. and D.M. Gann (2010), How Open Is Innovation?, Research Policy 39, 699-709.

Damanpour, F. (1992), Organizational Size and Innovation, Organization Studies 13, 375-402.

Doloreux, D. (2005), Regional Innovation Systems: Current Discourse and Unresolved Issues, Technology in Society 24, 243-263.

Dosi, G., F. Malerba, O. Marsili and L. Orsenigo (1997), Industrial Structures and Dynamics: Evidence, Interpretations and Puzzles, Industrial and Corporate Change 6, 3-24.

Feldman, M.P. (2001), The Entrepreneurial Event Revisited: Firm Formation in a Regional Context, Industrial and Corporate Change 10, 861-891.

Godoe, H. (2012), Innovation Theory, Aesthetics and Science of the Artificial after Herbert Simon, Journal of Knowledge Economy 3, 372-388.

Griliches, Z. (1979), Issues in Assessing the Contribution of Research and Development to Productivity Growth, Bell Journal of Economics 10, 92-116.

Hall, B.H. (2011), Innovation and Productivity, Nordic Economic Policy Review, 167-204.

Hayek, F. (1945), The Use of Knowledge in Society, American Economic Review $35,19-30$. 
Henderson, R. and I. Cockburn (1996), Scale, Scope and Spillovers: The Determinants of Research Productivity in Drug Discovery, RAND Journal of Economics 27, 32-59.

Jaffe, A., M. Trajtenberg and R. Henderson (1993), Geographical Localization of Knowledge Spillovers as Evidenced by Patent Citations, Quarterly Journal of Economics 108, 577-598.

Klepper, S. (2001), Employee Startups in High-Tech Industries, Industrial and Corporate Change 10, 639-674.

Klepper, S. and S. Sleeper (2005), Entry by Spinnoffs, Management Science 51, 1291-1306.

Krugman, P. (1991a), Increasing Returns and Economic Geography, Journal of Political Economy 99, 483-499.

Krugman, P. (1991b), History and Location: The Case of the Manufacturing Belt, American Economic Review 81, 80-83.

Krugman, P. (1993), First Nature, Second Nature and Metropolitan Location, Journal of Regional Science 33, 129-144.

Landry, C. (2008), The Creative City: A Toolkit for Innovators, 2nd edn, Earthscan, London.

Lichtenthaler, U. and E. Lichtenthaler (2009), A Capacity-Based Framework for Open Innovation: Complementing Absorptive Capacity, Journal of Management Studies 46, 1315-1338.

Link, A.N. and D.S. Siegel (2007), Innovation, Entrepreneurship and Technological Change, Oxford University Press, New York, NY.

Love, J.H. and S. Roper (2009), Organizing the Innovation Process: Complementarities in Innovation Networks, Industry and Innovation 16, 273-290.

March, J.G. (1991), Exploration and Exploitation in Organizational Learning, Organization Science 2, 71-87.

McGuirk, H. and D. Jordan (2012), Local Labour Market Diversity and Business Innovation: Evidence from Irish Manufacturing Businesses, European Planning Studies 20, 1945-1960.

Mohnen, P. and B.H. Hall (2013), Innovation and Productivity: An Update, Eurasian Business Review 3 (1), 47-65.

Mowery, D.C. (1983), The Relationship between Intrafirm and Contractual Forms of Industrial Research in American Manufacturing 1900-1940, Explorations in Economic History 20, 351-374.

Nelson, R.R. and S. Winter (1982), An Evolutionary Theory of Economic Change, Belknap Harvard Press, Cambridge, MA.

Nijkamp, P. (2003), Entrepreneurship in a Modern Network Economy, Regional Studies 37, 395-405.

Penrose, E.T. (1959), The Theory of the Growth of the Firm, John Wiley \& Sons, New York, NY.

Quigley, J.M. (1998), Urban Diversity and Economic Growth, Journal of Economic Perspectives 12, 127-138.

Roper, S., J. Du and J. Love (2008), Modelling the Innovation Value Chain, Research Policy 37, 961-977.

Rosenberg, N. (1994), Exploring the Black Box: Technology, Economics, and History, Cambridge University Press, Cambridge. 
Schmidt, T. and C. Rammer (2007), Non-technological and Technological Innovation: Strange Bedfellows? Working Paper 07-052, ZEW, Mannheim.

Schumpeter, J.A. (1934), The Theory of Economic Development, Harvard University Press, Cambridge, MA.

Schumpeter, J.A. (1942), Capitalism, Socialism, and Democracy, Harper \& Row, New York, NY.

Shapero, A. (1984), The Entrepreneurial Event, in C.A. Kent (ed.), The Environment for Entrepreneurship, Lexington Books, Lexington, MA, 21-40.

Sorensen, O. (2003), Social Networks and Industrial Geography, Journal of Evolutionary Economics 13, 513-527.

Storper, M. and A. Venables (2004), Buzz: Face-to-Face Contact and the Urban Economy, Journal of Economic Geography 4, 351-370.

Szarka, J. (1990), Networking and Small Firms, International Small Business Journal 8 (2), 10-22.

Takeishi, A. (2001), Bridging Inter- and Intra-firm Boundaries: Management of Supplier Involvement in Automobile Product Development, Strategic Management Journal 22, 403-433.

Teece, D.J. (1986), Profiting from Technological Innovation: Implications for Integration, Collaboration, Licensing and Public Policy, Research Policy 15, 285-305.

Wernerfeldt, B. (1984), A Resource-Based View of the Firm, Strategic Management Journal 5, 171-180.

Zahra, S.A. and G. George (2002), Absorptive Capacity: A Review, Reconceptualization, and Extension, Academy of Management Review 27, 185-203. 